Discussion Paper No. 13-011

\title{
Do we Need a Separate Banking System?
} An Assessment

Gunnar Lang and Michael Schröder

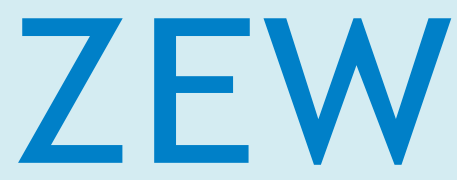

Zentrum für Europäische Wirtschaftsforschung $\mathrm{GmbH}$

Centre for European Economic Research 
Discussion Paper No. 13-011

\title{
Do we Need a Separate Banking System? An Assessment
}

\author{
Gunnar Lang and Michael Schröder
}

Download this ZEW Discussion Paper from our ftp server:

http://ftp.zew.de/pub/zew-docs/dp/dp13011.pdf

Die Discussion Papers dienen einer möglichst schnellen Verbreitung von neueren Forschungsarbeiten des ZEW. Die Beiträge liegen in alleiniger Verantwortung der Autoren und stellen nicht notwendigerweise die Meinung des ZEW dar.

Discussion Papers are intended to make results of ZEW research promptly available to other economists in order to encourage discussion and suggestions for revisions. The authors are solely responsible for the contents which do not necessarily represent the opinion of the ZEW. 


\section{Non-technical summary}

Motivated by the current discussion on different separate banking systems, we provide an overview of the different systems, question them and outline their effect on systemic stability and the German banking sector. The results show that the various separate banking systems only play a minor role in reducing and limiting systemic risk. They only marginally contribute to solving conflicts of interest and can even be detrimental to banking business diversification. A separate banking system could, however, facilitate banking supervision by reducing the banking system's complexity. Furthermore, credible threats to not support investment banks with federal resources in times of crisis could lead to a more adequate incentives structure of suppliers of equity and outside capital. More efficient measures to further reduce systemic risk in the financial sector should, however, use different levers, such as additional minimum regulatory capital requirements. 


\section{Das Wichtigste in Kürze}

Ziel unserer Studie ist es, ein umfassendes Bild über die derzeit diskutierten verschiedenen Trennbankensysteme zu liefern, die bestehenden Überlegungen kritisch zu hinterfragen und Folgen einer möglichen Umsetzung in Bezug auf die Systemstabilität sowie Bankenstruktur in Deutschland aufzuzeigen. Die Ergebnisse zeigen, dass die unterschiedlichen Trennbankensysteme nur einen eher untergeordneten Beitrag zur Reduktion und Begrenzung von Systemrisiko leisten können. Für die Lösung von Interessenkonflikten scheinen sie keinen signifikanten Beitrag zu leisten und hinsichtlich der Diversifikation des Bankgeschäfts könnten sie sogar nachteilig sein. Ein Trennbankensystem könnte allerdings die Bankenaufsicht durch die Reduktion der Komplexität des Bankensystems etwas einfacher machen. Außerdem könnte die glaubhafte Drohung, die Investmentbanken im Falle einer Krise nicht durch staatliche Zuschüsse zu unterstützen, zu einer ökonomisch adäquateren Anreizstruktur der Eigen- und Fremdkapitalgeber führen. Effiziente Maßnahmen zur weiteren Reduktion des Systemrisikos im Finanzsektor sollten aber besser an anderen Hebeln ansetzen, wie etwa zusätzlichen Erfordernissen hinsichtlich des regulatorischen Mindesteigenkapitals. 


\title{
Do we need a separate banking system? An assessment
}

\author{
Gunnar Lang1 and Michael Schröder ${ }^{2}$ \\ Centre for European Economic Research (ZEW), Mannheim, Germany
}

\begin{abstract}
Motivated by the current discussion on different separate banking systems, we provide an overview of the different systems, question them and outline their effect on systemic stability and the German banking sector. The results show that the various separate banking systems only play a minor role in reducing and limiting systemic risk. They only marginally contribute to solving conflicts of interest and can even be detrimental to banking business diversification. A separate banking system could, however, facilitate banking supervision by reducing the banking system's complexity. Furthermore, credible threats to not support investment banks with federal resources in times of crisis could lead to a more adequate incentives structure of suppliers of equity and outside capital. More efficient measures to further reduce systemic risk in the financial sector should, however, use different levers, such as additional minimum regulatory capital requirements.
\end{abstract}

Keywords: Banking Regulation, Commercial and Investment Banking, Financial Crises JEL-Classification: G01, G18, G24

\footnotetext{
${ }^{1}$ Gunnar Lang, Centre for European Economic Research (ZEW), Department of International Finance and Financial Management, P.O. Box 1034 43, 68161 Mannheim, Germany, Phone +49 6211235 372, Email lang@zew.de

${ }^{2}$ Michael Schröder, Centre for European Economic Research (ZEW), Department of International Finance and Financial Management, P.O. Box 1034 43, 68161 Mannheim, Germany, Phone +49 6211235 140, Email schroeder@zew.de
}

Acknowledgement: Our analysis is based on a research project funded by the Bundesverband Öffentlicher Banken Deutschlands (VÖB), Berlin, and was carried out in collaboration with our colleagues Christian David Dick and Lena Jaroszek. We thank them, the participants of the 46th Research Seminar in Radein as well as Stefan Becker, Brigitte Wesierski (both VÖB) for fruitful discussions. Moreover, we thank Anna-Lena Huthmacher, Maximilian Jäger, and Timo Schäfer for valuable research assistance. All errors are our own. 


\section{Introduction}

The current discussion about restructuring the European banking sector is centred around the introduction of a separate, specialist banking system. The most prominent contribution to this discussion is the European Commission's Expert Group on Reforming the Structure of the EU Banking Sector, whose report was published in October 2012 (Liikanen et al. (2012)). The overarching goals of introducing a separate banking system are a more stable financial system, an increase in the security of deposits and a reduction of public financial support needed to stabilise financial institutions. These goals were motivated by the developments of the financial crisis in the late 2000s. In a separate banking system, the particularly risky investment banking activities are separated from the other business areas of a universal bank (particularly from deposit banking, payment transactions and lending to individuals as well as businesses) and are assigned to a separate investment bank. This is designed to create two largely separate banking cycles. According to the Liikanen Report, both retail and investment banks will have to comply with regulatory capital requirements. In a separate system, however, investment banks would no longer be able to benefit (directly or indirectly) from the retail bank's deposit banking business. A potential advantage concerning refinancing costs, namely a lower risk premium due to possible government intervention in times of crisis, would also be eliminated. After all, investment banks, as opposed to retail banks, are to receive no or only very limited government support during a financial crisis.

The idea of two separate banking cycles is not recent. In 1933, the US introduced a separate, specialist banking system through the Glass-Steagall Act, in response to the Great Depression. It was designed to avoid conflicts of interest between different banking activities of a universal bank and thus to protect customers. This banking system was watered down over the years and finally resolved in the 1990s. Beforehand, influential studies had documented that the danger stemming from conflicts of interest in universal banks had been overestimated in the 1920s (Kroszner/Rajan (1994), White (1986)). Studies on the period after 1987, when important deregulation measures were taken, reach similar conclusions (e.g., Gande et al. (1997), Gande et al. (1999), Mullineaux (2002), Focarelli et al. (2011)).

The aim of our study is to provide a comprehensive overview of the different separation approaches currently discussed, to question existing ideas and to present the repercussions of a separation for the German banking system and the stability of the banking sector. 
The analysis is structured as follows. Chapter II describes and discusses current proposals for the introduction of a specialist banking system. Building up on this, in Chapter III, we discuss the repercussions of the introduction of such a system for Germany and analyse whether a separate banking system can improve the stability of the banking sector in general. Chapter IV concludes.

\section{Overview of the Current Reform Proposals}

The introduction and design of a separate banking system is the topic of public and academic debate. Two options are already being implemented: the so-called Volcker Rule (included in the Dodd Frank Act) in the US and the proposals by the Vickers Commission in the UK. The latter is based on a 2009 OECD proposal, which is centred on so-called NonOperating Holding Company Structures (NOHC). This approach has also been considered by the Liikanen Report. The current approaches will be discussed in this chapter.

\subsection{OECD proposal ${ }^{3}$}

In 2009, OECD researchers Blundell-Wignall et al. (2009) published a proposal to create a non-operating holding company (NOHC) structure for banks. They analysed whether a restructuring was necessary, and if so in what way, to stabilise the banking sector, especially with an eye to the too-big-to-fail issue. The authors come to the conclusion that the proposals on a financial market reform collated by the G-20 at the 2009 financial summit in Pittsburgh and designed to increase financial market stability (esp. Basel III) are not sufficient. An NOHC structure proposes the operative separation of individual business areas of a (universal) bank under one umbrella company. Each legally independent entity has its own capital base which is a priori non-transferrable between the entities. Only the umbrella company is entitled to borrow on the capital market and can then invest these resources in the different entities, but it is not entitled to pursue banking activities itself. Excluding customer deposits from liability for losses of the investment bank addresses the too-big-to-fail problem. This type of separation would also facilitate the liquidation of an insolvent business branch. Each

\footnotetext{
${ }^{3}$ The proposal by German candidate for the chancellorship, SPD's Peer Steinbrück on the introduction of a separate banking system largely follows that of the OECD (Steinbrück (2012)) and will thus not be considered separately.
} 
business unit has to develop its own "living will" for a potential insolvency and joint and several liability among the separated business units is excluded.

This means that there shall be no intermeshing of staff that could water down the separation, so that every entity has its own board of management, supervisory board and reporting. Despite a complete legal separation, the holding company is allowed to fulfil tasks (e.g. IT and Marketing) which may be used by all entities in order to create economies of scale and scope.

\subsection{Vickers Commission and White Paper}

In June 2010, the UK government set up the Independent Commission on Banking (ICB) chaired by the former Governor of the Bank of England, Sir John Vickers. The Commission's goal was to create a stable and efficient banking system and secure people's savings deposits. To achieve this goal, business units handling deposits were to be strictly shielded from other banking areas ("ring fencing"). The proposal was published in late 2011 and served as the basis for a draft law published by the UK government in June 2012 as a White Paper. The White Paper included many of the recommendations made by the Commission. The government seeks to pass this law by the end of the current legislature in May 2015 and fully implement it by 2019. The draft law calls for a ring fence between the economically relevant banking areas - traditional retail banking with deposit banking and lending - and the areas that are less important for the whole economy. Passing through losses in the investment banking branch to retail banking would thus become impossible. Client deposits under a certain threshold are to be assigned to the separated business unit (White Paper (2012)). ${ }^{4}$

The Vickers Commission categorises financial services as: (1) exclusively permissible for ring-fenced banks, (2) prohibited for ring-fenced banks, and (3) permitted financial services which may be offered by ring-fenced banks (Sachverständigenrat (2011), p. 161). The White Paper (2012) stipulates the following rules for ring-fenced banks:

1. Higher capital requirements apply in a ring fence than for other banking activities. A tier-1 capital ratio of 10 to $13 \%$ is planned, as well as an overall capital ratio (tiers 1 and 2) of up to $17 \%$ for systemically important banks (SIBs). Outside of the ring fence, the - lower Basel III requirements apply.

\footnotetext{
${ }^{4}$ The threshold has yet to be determined, but thresholds from 250,000 to 750,000 GBP are being discussed. The same holds true for company deposits. Their threshold may be set between 6.5 and 25 million GBP (White Paper (2012)).
} 
2. The leverage ratio ${ }^{5}$ is set at $3 \%$, acknowledging the respective Basel III criteria as sufficient.

3. Lending to other banks or financial institutions outside of the ring fence (e.g. insurers) is prohibited.

4. Transactions between the ring-fenced entity and the remaining financial institutions are limited and have to be treated as business with third parties in terms of risk management and financial supervision.

5. Financial services for clients outside of the European Economic Area (EEA) may not be carried out.

As in the OECD structure, the two business areas are to be separated legally, i.e. each entity has to set up its own reporting, board of management and supervisory board. In contrast to the fixed capital base, the entities may transfer capital between the different business areas, as long as each entity complies with its specific capital requirements. These measures are planned to enter into force in 2019. Therefore, its effects will only become visible later on.

\section{Discussions on Vickers and the White Paper}

There have been mixed responses from the UK financial industry. Some assume that diversification stemming from different business areas may decrease and thus make the overall banking business riskier. On the other hand, such a law is not expected to make banks and other financial institutions leave the financial centre of London, as the investment industry there would not be regulated more strictly than in other financial centres. ${ }^{6}$

In terms of higher capital requirements, The Economist (2011) sees similarities between the Vickers Commission's proposal and the Swiss banking reform, which prescribes a capital ratio of 19\%. Chow/Surti (2011) see difficulties in defining “economically important” banking activities. The authors also doubt whether ring-fencing is sufficient to minimise contagion risk. In its annual report 2011/2012, the Sachverständigenrat (2011) (German expert advisory council) for the assessment of the German economic development criticises that the Vickers Commission's proposal might have an adverse effect on international reform efforts towards a uniform prudential supervision through a "geographic splitting of financial institutions”. This

\footnotetext{
${ }^{5}$ The leverage ratio is essentially the ratio between tier-1 capital to the bank's non-risk-weighted assets.

${ }^{6}$ A Financial Times (2011) article assumes that the location choice for financial activities is made first and foremost based on long-term business strategies and that, therefore, a more profound change in business models would have to take place to motivate a change in location. This assumption meets the results of Lang (2012), who analyses determinants of location attractiveness of financial centres.
} 
is because according to the Vickers Report, only private customers located in the UK have to be ring-fenced; for all other clients in the European Economic Area, ring-fencing is merely an option. Therefore, retail banks outside of the EEA can also remain outside of the ring fence. The Vickers Commission therefore hampers global efforts to create a supranational supervisory authority (Sachverständigenrat (2011)).

\subsection{Volcker Rule}

The Volcker Rule is part of the Dodd-Frank Wall Street Reform and Consumer Protection Acts and was signed into law by US President Obama in late July 2010. It was supposed to enter into force by July 2012, but has not yet done so due to politically motivated delays. ${ }^{7}$ Other parts of the Dodd-Frank Act have been successfully put into practice. ${ }^{8}$ According to this proposal, banks with deposit business are subject to further regulations. Compliance with these regulations is a prerequisite for inclusion into the federal deposit insurance scheme (Federal Deposit Insurance Corporation). ${ }^{9}$ For business operations, this means: (1) a prohibition of short-term proprietary trading, (2) a limit on investments in assets defined as "risky" and (3) a restriction of mergers (see Dodd-Frank-Act (2010), Sec. 619):

1. "Short-term“ is defined as a holding period of less than 60 days. Proprietary trading with US bonds or bonds of companies or institutes with close links to the government is not subject to this prohibition. Providing liquidity for customers (market-making) and hedging are permitted.

2. Assets considered to be "very risky" are private equity funds and hedge funds. In order to limit funds financed by banks, banks may only hold a maximum of $3 \%$ of fund volume and may only invest a maximum of $3 \%$ of their tier-1 capital in such financial instruments.

3. Mergers which would result in a retail bank with a total balance of more than $10 \%$ of the aggregate US banking market are prohibited.

\section{Discussions on the Volcker Rule}

Chow/Surti (2011) fear the rise of problems for the regulatory categorisation of business areas. According to the authors, the definition of permitted hedging activities is too vague, making it almost impossible to distinguish these from prohibited activities. The authors also

\footnotetext{
${ }^{7}$ In early 2012, the FED published a statement saying the Volcker Rule was not properly thought out. The definition of prohibited banking activities was seen as a particularly big issue (see Tarullo (2012)).

${ }^{8}$ Two examples are the introduction of a new supervisory authority for financial services or the new federal institution for customer protection (Consumer Financial Protection Bureau (CFPB)).

${ }^{9}$ This also applies to foreign entities who accept deposits in the US.
} 
fear a potential shift of risks to shadow banks, where they would be difficult to monitor. However, new laws and regulations will take years to show their effect even after complete implementation, due to the high number of transition periods of up to 144 months (Liikanen (2012)). These transition periods are conditional on the size of a bank and its involvement in risky assets. Larger banks are granted longer transition periods. Another point of critique is that the Volcker Rule could limit companies' supply of capital market products and render market making more expensive (e.g. Duffie (2012)). EU Commissioner Barnier points out a potential drop in demand for European government bonds due to restricted proprietary trading under the Volcker Rule. This could intensify the debt crisis of the affected European countries (Wall Street Journal (2012)).

The Volcker Rule does create new requirements for mergers in order to limit the size of individual banks relative to the financial system. However, the intended cluster risk reduction only applies to new cases and does not affect the size of existing financial institutions. The Volcker Rule does not limit business activities of financial services providers that have a different legal form than banks, which could be an advantage for insurance companies and private equity firms (The Economist (2010)).

\subsection{The Liikanen Report}

When the ICB's detailed proposal and the introduction of the Volcker Rule in the US took shape, the EU Commission for the Internal Market and Services instructed an Expert Group ("Liikanen Group”) in early 2012 to find a solution tailored to the needs of the EU. In early October 2012, the Liikanen Group submitted its final report. Similar to Altunbas et al. (2011), they found that "no particular business model fared particularly well, or particularly poorly in the financial crisis” (Liikanen et al. (2012), p. 99). Instead, the Liikanen Group found that the causes of the financial crisis were "excessive risk-taking - often in trading highly-complex instruments [. . .] - and excessive reliance on short-term funding” (Liikanen et al. (2012), p. 99).

In order to counteract these developments, the framework set by Basel III and CRD III/IV are to be supported by stricter capital and risk management requirements. Furthermore, the expert group proposes to make efficient consolidation plans compulsory, to introduce "bail-in" instruments ${ }^{10}$ for a stronger loss share of private investors, as well as to secure property investments with more capital. In addition, supervisory authorities are to be strengthened by easier supervision, stricter risk management regulations, and the introduction of effective

\footnotetext{
${ }^{10} \mathrm{~A}$,bail-in“ instrument triggers the conversion of debt into equity in a previously defined crisis scenario.
} 
sanctions. The rules governing the payment of bankers should furthermore be tightened. The greater share of variable pay stipulated by CRD III is to include more "bail-in" instruments so that the management has a share in losses. This is considered a crucial step in building up the public's confidence in a just financial system. The group of authors in Liikanen et al. (2012) comes to the conclusion that separating risky trading activities in a separate banking unit ("investment bank”) is necessary to guarantee financial stability. The Liikanen Group proposes two alternative ways to separate commercial and investment banks:

\section{Avenue 1}

This option calls for the introduction of an additional, non-risk-weighted capital buffer for all banks whose investment activities exceed a certain threshold. The dimensions of this buffer depend on the volume of trade activities. A higher capital buffer is also considered for banks with a high share of deposit financing in order to further protect retail banks from the higher risk incurred from investment banking activities. In a second step, these banks' "restructuring and liquidation plans" have to be scrutinised by the supervisory authorities. In these plans, banks are to explain how they would prevent losses in the investment branch from spilling over to the retail branch (this corresponds to the OECD proposal's "living will”) in case of a crisis. If the supervisory authorities deem the banks' plans to be insufficient, a legal separation of investment banking from retail banking becomes compulsory. This scrutinization basically requires a banking union with the same supervisory rules across countries (level playing field). Otherwise, there would be national incentives to treat this issue differently, which could lead to differences in the attractiveness of location (see Lang (2012)).

As in the OECD proposal, a separation of banking units makes it impossible to finance investment banking with deposits or to move capital between the two entities (BlundellWingall et al. (2009)).

\section{Avenue 2}

This approach does not require previous scrutinization by the supervisory authorities for a separation of investment activities. Rather, exceeding a certain numerical threshold for a bank's investment business calls for a separation. The Liikanen Report discusses both a complete separation of investment activities and the option to only separate the volume exceeding 
the threshold. ${ }^{11}$ As in Avenue 1, the bank will be separated into two legally independent banking units, which, similar to the British system, have to have their own management and reporting and which are not allowed to transfer capital between each other. One exception is a retail bank in distress. Here, the investment unit can help out with capital. However, capital requirements have to be observed, which require an additional capital buffer for the investment unit (as in Avenue 1). Furthermore, retail banking entities are not allowed to be owner or property of an internal or external investment banking unit.

In both Avenues, the Liikanen Group proposes these numerical thresholds: Investment activities must not exceed (1) a volume of 15 to $25 \%$ of the total balance sheet or (2) a total maximum value of 100 billion euro.

According to Liikanen not all investment banking activities are affected by a separation but only the riskiest. Particularly proprietary trading with securities and derivatives and other activities in the securities and derivatives markets are to be separated. The latter affects all trading positions in market making. Trading activities within a bank’s own asset and liability management are an exception. The report lists further activities that should be part of a separate investment unit, ${ }^{12}$ as well as those which should continue to be allowed in the remaining banking unit, but which have to be restricted nonetheless. ${ }^{13}$

If the supervisory authorities require a splitting of the bank, the two resulting units can continue operation as two legally independent entities or can be bundled underneath the umbrella of a holding (NOHC structure). Bundling can evoke economies of scale and scope. However, defining numerical thresholds will be very difficult and require continuous scrutinization. The Liikanen Group assumes that refinancing banks will become more costly, which could in turn, together with less diversification options, make banking products more expensive.

\section{Discussion on the Liikanen proposal}

One may assume that defining thresholds for the permitted share of investment activities may be an incentive for banks to fulfil the (same) return expectations with riskier activi-

\footnotetext{
${ }^{11}$ See Liikanen et al. ((2012), p. 98). The latter option is designed to consider diversification benefits. However, whether a separation of only those investment activities exceeding the threshold can result in an independent, surviving entity is doubtful.

${ }^{12}$ Loans and brokerage for hedge funds, off-balance-sheet business and investments in private equity.

${ }^{13}$ Lending business with companies, foreign trade financing, consumer credit business, mortgages, inter-bank loans, shares in loan syndication, securitization concerning refinancing, wealth management and asset management, as well as arrangements with money market funds.
} 
ties. This means a bank could stay below the threshold but yield an average return which, before, it was only able to reach by exceeding the threshold.

Avenue 1 especially leaves room for interpretation and therefore uncertainties for banks concerning their business model. These uncertainties firstly affect the supervisory authority responsible for the scrutinization of restructuring and liquidation plans of banks with a significant commercial business. The wording of the Liikanen Report suggests concessions to the status quo: Scrutinization is carried out by the responsible supervisory authority according to EU-wide parameters. However, the Report's own discussion of the proposal already suggests that a uniform supervisory framework in the Eurozone with a central supervisory authority is essential. Major uncertainties also arise because the criteria for the assessment of restructuring and liquidation plans are not specified in more detail. The Liikanen Report only mentions that the risk positions should be assessed with a view to market size and that the complexity of trade instruments and organisational structures of a bank have to be considered. ${ }^{14}$

The public has often applauded the Liikanen Group's approaches because they facilitate the monitoring of large, complex universal banks as well as their liquidation in times of crisis. However, the thresholds (15-25\% of the total balance sheet or 100 billion euros) are viewed as too high, as only few banks would fall into that category (e.g. Financial Times (2012)). The Economist (2012) detects good points in the Report but criticises that it focuses too strongly on risky banking activities which are to be separated rather than identifying those business activities that are relevant for the real economy and should therefore be protected. Many industry representatives have welcomed the Liikanen Report and praise its consideration of the needs of banks and the advantages of a universal banking system (Bloomberg (2012)). The rating agency Fitch favours the idea of securing property investments with more capital in order to limit potential losses in this sector (Reuters (2012)). British business lawyers criticise the Liikanen Report's deviation from the White Paper (2012). British banks would have to comply with both, which would entail a considerable legal effort (e.g., McNulty (2012)).

\footnotetext{
${ }^{14}$ „The triggers would be related to the scale of the risk positions and their relation to market size, as large positions are difficult to wind down, particularly in a market stress situation. The triggers would also be related to the complexity of the trading instruments and organization (governance and legal structure) of the trading activities, as these features materially affect the resolvability of trading operations“ (Liikanen et al. (2012), p. 96).
} 


\section{Effects of the Proposals}

\subsection{Effects of a separate banking system on the stability of the banking sector}

Investment banks are spun off so that, in a financial crisis, the taxpayer only has to pay for saving (part of) the retail banks, while investment banks, which are deemed economically less important can go bankrupt. ${ }^{15}$ Suppliers of equity and debt capital to investment banks could thus lose their entire capital invested. The risk premia they demand should rise accordingly. The higher price for capital should, ceteris paribus, lead to a slower growth of the investment banking unit.

A further advantage of a separate banking system as pointed out by the Liikanen Report is that the banking system's structure becomes less complex and that higher transparency makes banking supervision easier. These arguments support the introduction of a separate banking system in order to stabilise the banking sector. Empirical research is less conclusive, but there are indications that universal banks with a relatively low share in investment banking are less prone to crises than their alternative of pure investment and retail banks.

There is clear evidence from research that investment banking is a particularly risky part of the banking business (see e.g. Demirgüc-Kunt/Huizinga (2010)). All empirical studies included in the following part of this chapter agree on this topic.

Adams et al. (2010) reach the conclusion that significantly negative effects could originate in hedge funds in times of crisis, which could move from investment banks (as the transmission channel) to retail banks and even the insurance sector. ${ }^{16}$ The study identifies hedge funds as one of the central risk factors for systemic crises and shows that investment banks would be adversely affected by them but could also function as transmission channel to other areas of the financial sector. The results of the study could be interpreted as that a separation of investment banks from retail banks and insurers could significantly reduce the systemic risk stemming from hedge funds. A separate banking system would leave most of the risk stemming from hedge funds in investment banks.

\footnotetext{
15 The Sachverständigenrat ((2011), p. 161-162) voices its doubts about this in its brief analysis of separate banking systems based on the Vickers Report. It assumes that the threat of not providing government means to rescue investment banks in times of crisis will be difficult to put into practice. The prevention of a systemwide domino effect in the banking sector by ring-fencing banks is also deemed improbable.

16 The study analyses the US financial sector and uses daily data for the period from April 2003 to the end of 2009. The results are confirmed by Schröder et al. ((2011), Chapter 3.4) for the extended period until December 31, 2010.
} 
Some studies have analysed the difference in returns and risk between various banking business models. Among other things, they address the question of whether, and in how far a "mix" of investment banking and retail banking would be sensible.

A relatively early study is that of Templeton/Severiens (1992). The authors analyse how different diversifications of the banking business affect US banks' share prices between 1979 and 1986. They find that business diversification made banks more stable in terms of less share price volatility. However, this is only an indirect result for the analysis of diversification benefits, because share prices serve as reference point, as opposed to a bank's success.

De Nicolo et al. (2004) find that banks with a broader services spectrum are subject to greater risk. The study is based on data on 500 financial institutions worldwide and analyses the time period from 1995 until 2000. The authors argue that larger banks with a wider range of services (universal banks) are willing to incur higher risks than smaller, specialised financial institutions and thus over-compensate potential diversification benefits.

Demirgüc-Kunt/Huizinga (2010) analyse 1,334 banks from 101 countries for the time from 1995 to 2007. They divide banking activities into interest business and all other business areas (non-interest business) $)^{17}$ and analyse the effects of the business model on return and risk. Their main finding is that a small share in investment banking activities (characterised by an emphasis on "non-interest business" and a larger share in short-term financing through the capital market) generates diversification benefits in the business model. ${ }^{18}$

Altunbas et al. (2011) analyse the effect of certain pre-crisis characteristics of banks on risk realised during the crisis. They analysed 1,100 banks in Europe and the United States. Characteristics such as size, equity, volume of loans granted, and financing structure were collated for the period of late 2003 to the third quarter of 2007. For the time of the financial crisis, from the end of 2007 until the end of 2009, measures for risk susceptibility of banks were calculated, such as the risk of bankruptcy and the amount of liquidity provided by the central bank. Altunbas et al. show that the size of a bank, relatively little equity, strong credit growth and little deposit funding lead to higher risk. The effect of the business model on risk seems to be non-linear: a greater share of deposit funding (and therefore a lower share in short-term capital market financing) lowers the risk of particularly risky banks disproportionately. In less risky banks, however, an increase in short-term capital market financing does not immediately lead to a significant risk increase. When applied to separate banking systems,

\footnotetext{
17 „Non-interest business“ includes as main parts commission business and proprietary trading.

${ }^{18}$ Diversification benefit denominates the idea, in portfolio theory, that higher returns can be generated at the same risk or the same return can be generated at a lower risk.
} 
the results of this study find that a small investment banking unit only marginally increases the overall risk of a low-risk retail bank. A split-up into retail and investment bank would therefore not be necessary for such banks.

Beltratti/Stulz (2012) analyse which banks were particularly affected by the financial crisis. Their study was conducted on about 220 large international banks from mid-2007 until late 2008. Banks with an ex ante high equity ratio, a high share of deposit funding and a focus on credit business were found to have performed relatively well. This study underlines the particular robustness of retail banks with a small share in investment banking.

While Demirgüc-Kunt/Huizinga (2010); Altunbas et al. (2011) and Beltratti/Stulz (2012) focus on large listed banks, Köhler (2012) also analyses smaller, non-listed banks and considers around 3,000 retail banks, savings banks and cooperative banks in 15 EU Member States over the period from 2003 until 2009. ${ }^{19}$ Similar to Altunbas et al. (2011), the study analyses influencing factors of banking risk. One of the main influencing factors is strong credit growth; the type of financing (capital market vs. deposits) does not seem to play an important role. An increase in non-interest business even lowers risk through a greater diversification of sources of income. This effect appears to be particularly strong in smaller banks. The author reasons that larger banks have more possibilities to carry out risky activities in non-interest business, which counter diversification benefits. ${ }^{20}$

The abovementioned empirical studies elaborate extensive implications for banking regulation and supervision:

A relatively low participation in investment banking activities improves the riskreturn ratio of universal banks (see Demirgüc-Kunt/Huizinga (2010)).

- However, there are indications that banks with a wider range of services tend to run higher risks and could thus over-compensate diversification benefits (see $D e$ Nicolo et al. (2004)).

- A low participation in investment banking will only marginally increase the overall risk of retail banks which are managed in a low-risk manner (see Altunbas et al. (2011)). A strict separation into retail bank and investment bank would therefore not be necessary for such banks.

An increase in investment banking activity (non-interest business) in relatively small banks could even lower risk through greater diversification of sources of

\footnotetext{
${ }^{19}$ Köhler does not include investment banks.

${ }^{20}$ Such as risky off-balance sheet activities, proprietary trading.
} 
income, while this connection cannot be found in large banks (see Köhler (2012)).

- A main source of systemic risk in the financial sector seems to be hedge funds.

Investment banks serve as a transmission channel for risks to other areas of the financial sector (retail banks, insurance companies) (see Adams et al. (2010)).

These results rather speak against the introduction of a pure separate banking system, but in favour of strictly limiting the influence of investment banking on the universal bank. The Liikanen Report's Avenue 2 takes account of this fact by proposing a compulsory separation into investment bank and retail bank only above a threshold of 15 to 25\% (Liikanen et al. ((2012), p.101)). This would permit a significant participation in investment banking without requiring a separate investment bank. However, under Avenue 2, a positive diversification effect would almost be eliminated after a complete separation of the investment bank. ${ }^{21} \mathrm{~A}$ possible consequence is reduced stability for both retail bank and investment bank.

This supports the introduction of Avenue 1 in combination with a stricter limit on a bank’s share in investment banking. However, the Liikanen Report does not make clear suggestions for the allocation of banking activities to the two separated entities. According to Liikanen et al. ((2012), p.98), it would be possible to only transfer those investment activities to the investment banking unit which exceed the $15-25 \%$ threshold. This would at least constitute a diversification advantage for the retail bank.

Empirical studies such as Altunbas et al. (2011) and Köhler (2012) use their empirical findings to argue that the main factors for systemic risk are strong credit growth, insufficient equity and a large share of short-term capital market financing. These risk factors are already considered in the new Basel III regulations, e.g. through the introduction of higher regulatory capital requirements, the anti-cyclical capital buffer or the minimum liquidity requirement. The discussion on separate banking systems does not significantly touch upon these main risk factors and therefore seems to not play a central role in the debate on how to reduce systemic risk.

\subsection{Effects on the German banking structure}

Under the Volcker Rule, banks wishing to continue using the deposit-guarantee scheme and access to central bank resources have to either legally separate their investment business

\footnotetext{
${ }^{21}$ Diversification benefits could still arise in this case because not all investment banking activities have to be transferred to the investment bank. According to the Liikanen Report, proprietary trading and other trading activities are to be transferred while M\&A business, which is not systemically important, may remain in the retail bank.
} 
or limit its operation in compliance with regulation. Since customer investments continue to be permitted, however, they would still be able to offer a wide range of products without a spin-off of their investment banking unit. Nevertheless, the Volcker Rule has to be viewed as a solution tailored to the needs of the US banking market, which could lead to distortions of various magnitudes in different banking systems. Introducing the Volcker Rule would not entail a great change for savings banks and regional banks (Landesbanken), since savings banks do not participate in business of risky assets and are not permitted to act outside of the savings bank sector (Becker/Peppmeier (2011), p. 86). Savings banks and regional banks are not part of the national deposit-guarantee schemes, but secure their customers' deposits through institutional guarantee and savings bank support funds (Sparkassenstützungsfonds). Should the exclusion from deposit-guarantee schemes of institutions active in short-term proprietary trading be transferred to these support instruments, and should regulations on central bank funds come into force, regional banks would have to adjust their business according to the regulations. Since customer-induced short-term proprietary trading is permitted under the Volcker Rule, regional banks could still offer a wide range of products for corporate customers. Cooperation between savings banks and regional banks in an association is not affected.

Vickers could pose a problem for the German public banking sector. An issue for cooperation between savings banks and regional banks could be the prohibition of transactions between the ring-fenced entities (savings banks) and the non-ring-fenced entities (regional banks and DekaBank). According to the regulations, the ring-fenced retail units would not be allowed to grant loans to or participate in non-ring-fenced financial institutions. Furthermore, savings banks would have to comply with the additional capital requirements.

Those proposals calling for a separation of the two business units under the umbrella of a holding (OECD, Steinbrück, Liikanen) should only apply to large German banks (such as Deutsche Bank, Commerzbank, LBBW). This should reduce the then-costly proprietary trading. In particular, refinancing the investment banking unit is expected to become much more expensive. The original OECD proposal should constitute a feasible model for savings banks and regional banks, since it largely corresponds to the existing structures in the sector. The adjustments by Steinbrück (2012), however, pose a problem regarding the prohibition of participation. The OECD touches upon this issue by indicating, in a not very detailed manner, that cooperation between savings banks and regional banks will continue to be possible. ${ }^{22}$

\footnotetext{
${ }^{22}$ Landesbank Berlin serves as a good example of a holding structure in the savings bank and regional banking sector. Under the umbrella of LBB Holding AG, Landesbank Berlin and Berliner Sparkasse, as universal banks, are responsible for customer business, while LBB Invest, as a fund provider, is responsible for capital
} 
Cooperation between savings banks and regional banks could be changed by Liikanen's Avenue 1 . This would be the case when a financial institution crosses the thresholds, which are deemed to be significant for the categorisation of trading activities. According to the current Liikanen proposals (size of the position "assets held for trading and available for sale" exceeds $15-25 \%$ of all assets) this could apply to LBBW. Figures published by the Association of German Public Banks (VÖB), however, show that almost all regional banks would be affected. Whether a separation of trading activities becomes reality depends on the credibility of the restructuring and liquidation plans to be submitted. If a prevention of spill-overs of losses from the investment bank to the retail unit is credible or if the responsible supervisory authority uses its discretionary scope for decision, a separation is not necessary. Nevertheless, regional banks would still be affected by the additional non-risk-weighted capital buffer requirements. These could even be higher than expected depending on the share of depositfunded refinancing. If trading activities remain underneath the threshold or if there is a "living will”, banks may continue to pursue all activities within the existing banking structures. The repercussions of Liikanen's Avenue 2 for the savings bank and regional banking sector are similar to those of Avenue 1. But since supervisory authorities cannot always take into account national characteristics in their decisions, the Liikanen group considers certain exceptions for associations, which it does not describe in more detail.

\section{Conclusion for Economic Policy and Banking Regulation}

This section presents the main findings of our study. A separate banking system is not necessary to prevent conflicts of interest within the banks. This is the result of many empirical studies analysing banks' business policy before the introduction of the Glass-Steagall Act in 1933 against the backdrop of the separate banking system in the US which was abolished in the late 1990s. These studies show that there were no systemic differences between the issuing activities of a universal bank and a pure investment bank.

None of the current reform proposals calls for a complete separation of all investment banking functions from the universal bank. The Volcker Rule in the US aims at restricting the investment banking participation of banks with deposit banking. Short-term proprietary trad-

market business. LBB Holding yielded an interest surplus of EUR 951 mio. in 2011, almost 3.5 times as much as the commission surplus (EUR 260 mio.). However, adjustments would have to be made due to the partial overlap in the boards of directors of holding parent and subsidiaries and concerning potential restrictions in operations for banks in the customer business. 
ing and high participation in risky assets are to be prohibited. The other proposals, on the other hand, aim directly at banks’ business structures. The Vickers Commission's proposals in the UK stipulate especially harsh requirements for the retail banking sector, strictly separating it from other banking units. The reform proposals by the OECD, Steinbrück and the Liikanen Group, however, focus on individual investment banking activities. According to Liikanen, proprietary trading with securities and derivatives and further risky activities are to be transferred to the investment bank.

Not all proposals on separate banking systems adequately address the association structures in the public banking sector. Problems are to be expected when cooperation in an association is no longer permitted, which would be the case under the Vickers Commission's proposal. The Volcker Rule and the proposals on NOHC structures, on the other hand, could be implemented relatively well in the association of savings banks and regional banks. The Liikanen Group's Avenue 1 on stabilising the banking sector would be particularly beneficial for public banks, as long as supervisory authorities use their scope for decision to take into account public banks' needs. However, it is not clear how to take German associations into consideration should Avenue 2 be introduced, which entails an automatic separation of the entire trading business when thresholds are exceeded.

A separate banking system reduces potential banking business diversification: A strict separation of investment banks from retail banks would diminish useful diversification effects, which could cause both retail banks and investment banks to become less stable.

The separation of investment bank and retail bank as proposed by the Liikanen Report takes account of potential diversification benefits of the universal bank by introducing thresholds. Since a separation is only recommended for a minimum participation in investment banking of 15 to 25\%, diversification benefits could still be reached by combining a smaller share of investment banking with a larger share of retail banking. However, diversification benefits from the banking business would largely be lost, especially for the investment bank, should a strict separation (Avenue 2) occur.

\section{Alternatives for a further regulation of investment banking}

The aim of separate banking systems is to remove the highly risky investment banking activities from the universal bank and manage it as a separate entity. This constitutes a strong intervention in existing banking structures and raises the question whether the risks stemming from investment banking could be minimised adequately with less effort. This section pre- 
sents two alternatives geared towards reducing the systemic risk stemming from investment banks. The general idea is to make existing ${ }^{23}$ or additional capital requirements conditional on the size of the investment business. Such a component of regulatory equity could be defined depending on the size of a bank's participation in investment banking relative to the overall bank size. ${ }^{24}$ This measure could be compulsory for all banks with a certain participation in investment banking or, alternatively, only for systemically important banks (e.g. global systemically important banks (G-SIB) or domestic systemically important banks (D-SIB)). Since proprietary trading constitutes a particularly risky part of investment banking, this equity requirement could also be defined as dependent on the size of a bank's proprietary trading.

A second alternative would be to link additional regulatory equity for banks to the size of a bank's hedge fund business. A good reason for this alternative is that lending to hedge funds is a main influencing factor for systemic risk stemming from investment banks. Contrary to the Volcker Rule, this regulation would not limit the maximum participation rate but would stipulate capital requirements and therefore the price for lending to hedge funds.

An advantage for banking supervision would be that banks cooperating with hedge funds are easier to regulate than hedge funds themselves, which in turn means that hedge funds could (indirectly) be regulated more easily. A disadvantage for banks would be that they would have to bear the burden (and costs) instead of hedge funds, which are more difficult to grasp.

These two alternatives would avoid the effort-intensive splitting of banks, which would also entail unforeseeable consequences for banks' business models. Nevertheless, these two approaches could set incentives to reduce investment banking participation. However, there already are comprehensive regulation reforms (Basel III, EU Directive on Alternative Investment Fund Managers ${ }^{25}$ ) whose repercussions would have to be known before introducing new measures.

\footnotetext{
${ }^{23}$ As, for example, the capital conservation buffer or the systemic buffer.

${ }^{24}$ As Avenue 1 of the Liikanen Report already calls for an additional minimum equity ratio based on the nonrisk-weighted investment banking activities this idea could be easily integrated in the proposal of the Liikanen group.

${ }^{25}$ DIRECTIVE 2011/61/EU of the European Parliament and of the Council of 8 June 2011 on Alternative Investment Fund Managers and amending Directives 2003/41/EC and 2009/65/EC and Regulations (EC) No 1060/2009 and (EU) No 1095/2010.
} 


\section{REFERENCES}

ADAMS, Z., R. FÜSS and R. GROPP (2010): Modeling Spillover Effects among Financial Institutions: A State-Dependent Sensitivity Value-at-Risk (SDSVaR) Approach, European Business School Research Paper Series no. 10-12, Oestrich-Winkel.

ALTUNBAS, Y., S. MANGANELL and D. MARQUES-IBANEZ (2011): Bank Risk during the Financial Crisis: Do Business Models Matter?, ECB Working Paper no. 1394, Frankfurt am Main.

BECKER, H and A. PEPPMEIER (2011): Bankbetriebslehre, 8th edition, Herne

BELTRATTI, A. and R. STULZ (2012): The Credit Crisis Around the Globe: Why Did Some Banks Perform Better?, Journal of Financial Economics, 105, 1-17.

BLOOMBERG (2012): BNP’s Villeroy says Liikanen Report Validates Universal Banking, 8.10.2012

BLUNDELL-WIGNALL, A., G. WEHINGER and P. SLOVIK (2009): The Elephant in the Room: The Need to Deal with What Banks Do, OECD Journal: Financial Market Trends, 2009/2.

CHOW, J. and J. SURTI (2011): Making Banks Safer: Can Volcker and Vickers do it?, IMF Working Paper no. 11/236, 1-34, Washington, D.C.

DEMIRGÜÇ-KUNT, A. and H. HUIZINGA (2010): Bank Activity and Funding Strategies The Impact on Risk and Returns, Journal of Financial Economics, 98(3), 626-650.

DE NICOLÓ, G., P. BARTHOLOMEW, J. ZAMAN and M. ZEPHIRIN (2004): Bank consolidation, internationalization, and conglomeration: Trends and implications for financial risk, Financial Markets, Institutions and Instruments, 13, 173-217.

DODD-FRANK-ACT (2010): Dodd-Frank Wall Street Reform and Consumer Protection Act, 111, Congress of the United States, Washington, D.C.

DUFFIE, D. (2012): Market Making under the Proposed Volcker Rule, Rock Center for Corporate Governance at Stanford University Working Paper no. 106, Stanford.

FINANCIAL TIMES (2011): UK moves bank rules closer to US, 11.04.2011.

FINANCIAL TIMES (2012): Missing pickets in Europe's new ring-fence, 5.10.2012.

FOCARELLI, D., D. MARQUEZ-IBANEZ and A. F. POZZOLO (2011): Are Universal Banks Better Underwriters? Evidence From the Last Days of the Glass-Steagall Act, ECB Working Paper Series no. 1287, Frankfurt am Main.

GANDE, A., M. PURI and A. SAUNDERS (1997): Bank Entry, Competition, and the Market for Corporate Securities Underwriting, Journal of Financial Economics, 54, 165-195.

GANDE, A., M. PURI, A. SAUNDERS and I. WALTER (1999): Bank Underwriting of Debt Securities: Modern Evidence, Review of Financial Studies, 10, 1175-1202.

INDEPENDENT COMMISSION ON BANKING (2011): Final Report, London. 
MCNULTY, L. (2012): Liikanen Report: market concerns, International Finance Law Review, 11.10.2012.

KÖHLER, M. (2012): Which Banks are more Risky? The Impact of Loan Growth and Business Model on Bank Risk-Taking, Deutsche Bundesbank Working Paper no. 33/2012, Frankfurt am Main.

KROSZNER, R. S. and R. G. RAJAN (1994): Is the Glass-Steagall Act Justified? A Study of the U.S. Experience with Universal Banking before 1933, American Economic Review, 84, 810-832.

LANG, G. (2012): Lessons of the Financial Crisis for the Attractiveness of European Financial Centers, ZEW Discussion Paper no. 12-080, Mannheim

LIIKANEN, E. at al. (2012): Final Report of the High-level Expert Group on Reforming the Structure of the EU Banking Sector, Brussels

REUTERS (2012): Liikanen proposals could address underestimated losses, 4.10.2012

ROTEN, I. C. and D. J. MULLINEAUX (2002): Debt Underwriting by Commercial BankAffiliated Firms and Investment Banks: More Evidence, Journal of Banking and Finance, 26, 689-718.

SACHVERSTÄNDIGENRAT (2011): Verantwortung für Europa wahrnehmen - Jahresgutachten 2011/2012, Sachverständigenrat zur Begutachtung der gesamtwirtschaftlichen Entwicklung, Wiesbaden.

SCHRÖDER, M., M. BORELL, R. GROPP, Z. ILIEWA, L. JAROSZEK G. LANG, S. SCHMIDT and K. TRELA (2011): The role of investment banking for the German economy: Final report for Deutsche Bank AG, Frankfurt/Main, ZEW-Dokumentation, no. $12 / 01$.

STEINBRÜCK, P. (2012): Vertrauen zurückgewinnen: Ein neuer Anlauf zur Bändigung der Finanzmärkte, SPD, Berlin.

TARULLO, D. (2012): The Volcker Rule, Testimony, Federal Reserve System, Washington D.C.

TEMPLETON, W. and J. SEVERIENS (1992): The effect of nonbank diversification on Bank Holding Companies, Quarterly Journal of Business and Economics, 31, 3-16.

THE ECONOMIST (2010): The Volcker Rule - Bang or whimper?, 24.06.2010.

THE ECONOMIST (2011): The Vickers Report - United they stood, 21.09.2011.

THE ECONOMIST (2012): The Liikanen Review - into the ring, 6.10.2012.

WALL STREET JOURNAL (2012): EU Red Flags Volcker, 27.01.2012.

WHITE, E. N. (1986): Before the Glass-Steagall Act: An Analysis of the Investment Banking Activities of National Banks, Explorations in Economic History, 23, 33-55. 
WHITE PAPER (2012): Banking reform: delivering stability and supporting a sustainable economy, HM Treasury and the Department for Business, Innovation and Skills, London 